\title{
GLAURA Y CARIOLANO, UNA ÓPERA NEOCLÁSICA DE IGNACIO GARCÍA MALO
}

\author{
Glaura y Cariolano, a neoclassical opera by Ignacio \\ García Malo
}

Felipe RODRÍGUEZ MORÍN

Instituto Feijoo de Estudios del Siglo XVIII

felipe.rodriguezmorin@asturias.org

Fecha de recepción: 16/10/2015

Fecha de aceptación: 6/07/2016

RESUMEN: A fin de emular las óperas italianas, se decidió en 1791 García Malo a confeccionar una pieza de ese tipo en el idioma castellano, para muestra de que la riqueza y armonía de nuestra lengua en nada tenía que envidiar a ninguna extranjera, y con la esperanza de que se formara en un futuro un teatro lírico como el italiano. A esta intención patriótica se le añadió, además, la de ensalzar las glorias de España en América y, a su través, hacer partícipe al destinatario de la obra de las virtudes del carácter hispano, en una época en la que algunos ya temían por la futura estabilidad política de las colonias de ultramar. Con el propósito de que el mensaje calara más eficazmente en el espectador, ajustó García Malo el texto enteramente a la estética neoclásica. Por lo que concierne a la música, a cargo de José Lidón, muy probablemente contribuyó a reforzar en el oyente ese efecto de revivir y cantar las pasadas grandezas de España.

Palabras clave: Glaura y Cariolano; García Malo; ópera española; drama neoclásico; patriotismo.

ABSTRACT: With the intention of emulating Italian operas, García Malo decided in 1791 to write one of these pieces in Spanish, in order to show that the richness and harmony of this language was comparable to that of any other foreign language, and in the hope that opera similar to Italian opera would be created in 
the future. Together with this patriotic intention was the aim of acclaiming Spanish splendour in America, and, through that, informing the audience of the work about the virtues of the Hispanic character, at a time in which some were worried about the future political stability of the overseas colonies. García Malo adapted the text entirely to neoclassical aesthetics, so that the message would more efficiently leave a mark on the spectator. As regards the music, composed by José Lidón, it most likely contributed to reinforcing in the listener the effect of reliving and singing the past glory of Spain.

Key words: Glaura y Cariolano; García Malo; Spanish opera; neoclassical drama; patriotism.

\section{LA GESTACiÓN DE UN PROYECTO NOVEDOSO}

Parece imprescindible comenzar este trabajo tratando de aclarar la posible confusión que se haya podido generar en lo que concierne a la paternidad de esta obra. Cierto es que tratándose de una ópera se hacía menester dotar de música al texto literario, y natural resulta que los estudiosos de esa disciplina propendan a ensalzar dicha parte y a su compositor por encima y en merma de la labor del poeta. Sin embargo, tal y como aquí nos proponemos argumentar, el objetivo primero y más sustancial de esta pieza, revestida con el brillante ornamento de la melodía, no estribaba simplemente en conmover al espectador con sus acordes ni en depararle un mero pasatiempo agradable, sino que sus aspiraciones iban bastante más allá; cuestión esta que, por otra parte, no impide ni estorba para reconocer que la belleza y armonía del canto muy probablemente le confirió un plus de calidad y perfección al producto final y, por ende, de eficacia en su propósito.

Por eso, y en aras de la intención que nos ocupa, debemos poner en cuestión las manifestaciones de García Fraile cuando continua y reiteradamente, incluso desde el propio título del artículo, señalaba a Lidón como el genuino autor de la obra (por ejemplo: "Drama heroico Glaura y Cariolano de José Lidón»: pp. 169 y 175; «esta obra de José Lidón», "Glaura y Cariolano de José Lidón»: p. 171), y por tanto también de la "Advertencia»: «[...] la breve introducción al Drama heroico Glaura y Cariolano de José Lidón "․ Por contra, a García Malo solo se le alude como de soslayo, en una nota a pie de página, y ciertamente que sin mucho

1. García Fraile, Dámaso. «Un drama heroico en verso castellano "Glaura y Cariolano” de Joseph Lidón, representado en Madrid, en el tercer centenario del descubrimiento de América". En Kleinertz, Rainer (ed.). Teatro y música en España (siglo XVIII). Actas del Simposio Internacional Salamanca 1994. Kassel-Berlín: Edition Reichenberger, 1996, pp. 145-176, p. 170. Más claramente aún le había adjudicado poco antes la elaboración del citado proemio, puesto que, con motivo de comentar ciertas frases del mismo, enuncia lo siguiente acerca de ellas: "Bien podemos afirmar que Lidón formula en muy pocas palabras un auténtico Manifiesto sobre la creación de un teatro lírico español en el año 1792». 
entusiasmo por parte del mencionado García Fraile: «De acuerdo con la información facilitada por el Dr. Kleinertz, el libreto [...] es de Ignacio García Malo (?-?)» (p. 160).

No obstante lo cual, para nosotros el efectivo promotor e impulsor de esta iniciativa no fue el significado José Lidón, sino un dramaturgo neoclásico, fiel seguidor de los cánones y preceptos de ese movimiento artístico, como desde luego fue el caso de Ignacio García Malo.

En testimonio de ello, sabemos que recabó del Consejo de Castilla -con inusitado apremio, además-, a través de un escrito firmado el 6 de julio de 1791, el oportuno permiso para la publicación del texto de la obra. Se escudaba Malo en ese papel para obtener la aprobación, si bien de forma indirecta y como de pasada, en el ascendiente y favor del conde de Floridablanca:

D. Ignacio García Malo oficial de la Rl. Biblioteca con la mayor veneración expone a V.S. que ha compuesto una operita intitulada El valor y Clemencia española en América con Glaura y Cariolano, la cual puesta en música por Dn. Josef Lidón se presentó al Exmo. Sr. Conde de Floridablanca, quien la remitió al Sr. Corregidor, y está ya con las censuras correspondientes para representarse el Lunes próximo como S. E. ha dispuesto después de su venida a Aranjuez; en cuya atención para que se pueda imprimir en el corto tiempo que queda junto con la introducción que acompaña, que también está ya parada por iguales censuras².

Fungía entonces García Malo, al menos de forma nominal, de oficial de la Real Biblioteca, aunque más que en ejercer ese empleo ocupaba sus días como secretario del patriarca de las Indias Antonino de Sentmanat, al frente de la Secretaría del Vicariato General de los Ejércitos y de la Real Capilla ${ }^{3}$. Y tal vez fuera en razón de esta circunstancia como Malo conociera, por un lado, a José Lidón, primer organista de dicha institución religiosa desde $1787^{4} \mathrm{y}$, por otro, tuviese acceso al secretario de Estado, José Moñino Redondo, conde de Floridablanca,

2. Archivo Histórico Nacional (en adelante AHN), Consejos, 5557-80.

3. Precisamente aludiendo a la Real Capilla, leemos un oficio del cardenal patriarca Sentmanat, de 18 de septiembre de 1790, remitido a Antonio Porlier, secretario de Gracia y Justicia, entidad de la que dependía la Biblioteca, en solicitud de la licencia real para que García Malo pudiese acompañar a dicho eclesiástico: "Estando empleado en la Real Biblioteca mi Secretario de Cámara Don Ignacio García Malo, y necesitándole yo en la próxima Jornada del Real Sitio de San Lorenzo no precisamente para mis asuntos propios, sino para evacuar algunos graves pertenecientes al Real Servicio y Capilla de S. M. [...]» (Biblioteca Nacional de Madrid, en adelante BNM, Archivo, caja 36-6).

4. Afamado compositor, natural de Béjar, fue José Lidón y Pérez clérigo de menores y colegial del Real Colegio de San Lorenzo, según descubrimos en la escritura de arrendamiento de un beneficio otorgada por él en San Lorenzo de El Escorial, el 13 de mayo de 1800, ante Pedro Martínez Villasana (Archivo Histórico de Protocolos de Madrid, leg. 33157, f. 91). Había sido también Lidón el encargado de musicalizar El Barón, ópera de Moratín antes de que fuera trocada en comedia (vid. "Trozos copiados de un escrito de Don Juan Antonio Melón, titulado Desordenadas y mal digeridas apuntaciones". En Obras póstumas de Moratín. Madrid: Imprenta de Rivadeneyra, 1868, t. III, p. 387). Para un mejor conocimiento de su biografía remitimos al mencionado trabajo de Dámaso GARCía FraILE, pp. 147-156. 
probablemente a través de su amigo José de Anduaga, oficial mayor en esa Secretaría.

Pero a pesar de la influencia exhibida por D. Ignacio, o tal vez precisamente a causa de ella -ya que por aquellas fechas la posición política de Floridablanca se hallaba debilitada-, tardó la obra en alcanzar el plácet burocrático para entregarse a la imprenta. Las prisas, entretanto, angustiaban a nuestro autor, quien por medio de una carta, de fecha incierta, dirigida a Pedro Escolano de Arrieta, secretario de la Sala de Gobierno del Consejo de Castilla (conservada en el mismo legajo del $\mathrm{AHN}$ ), recordaba lo perentorio de su demanda: "A ver qué novedad hay de la Licencia para imprimir la Operita, pues ya urge mucho». Sin embargo, el requerido beneplácito no fue dispensado por la Sala de Gobierno del Consejo de Castilla hasta el 20 de enero de 1792, previo pase, un par de días antes, por la censura de Joaquín Ezquerra, gran amigo, por cierto, de García Malo:

De orden de Vs. [Felipe Rivero y Valdés] he visto el Drama Alegórico intitulado Glaura y Cariolano que se ha servido remitir a mi censura; y no he hallado en el cosa alguna que se oponga a la Religión, buenas costumbres, y Regalías de S.M. antes si le juzgo muy digno de la publicación que solicita (AHN, leg. cit.).

Finalmente fue editado el drama ese mismo año de 1792 en la Imprenta Real, con la omisión del nombre del poeta, aunque sí con el del autor de la música, y con el título modificado respecto del transcrito por Malo en la antedicha solicitud de autorización: Drama Heroico en verso castellano, intitulado Glaura y Cariolano. Puesto en música por D. Joseph Lidón ${ }^{5}$, organista principal, y Vice-maestro de la Real Capilla de S. M., y representado en el Coliseo del Príncipe por la Compañía de Ribera ${ }^{6}$. Ese silencio sobre la identidad del escritor quizá coadyuvara a acentuar la responsabilidad de la obra en la persona del compositor, cuyo nombre y empleos sí que aparecían estampados en la portada ${ }^{7}$.

5. La parte musical de Glaura y Cariolano, conservada en BNM (M-1734) bajo el título de Sinfonía. Drama heroico en un Acto en verso castellano. Puesto en música por Dn. Josef Lidón. Año 1791, es elogiosamente comentada por Subirá: «Mucho me complace señalar la existencia de esta obra, escrita en partitura, e inaugurada con una "Sinfonia" [sic] para violines, clarinetes, violas, fagotes y violonchelos al unísono y "bassi". Contiene recitados, arias, dúos, tercetos y marchas... Un número requiere en la instrumentación una parte de "violette". La ópera de Lidón, examinada en conjunto, revela un apego más fatal que feliz a las tradiciones filarmónicas procedentes de suelo italiano» (SuBIrá, José. Historia de la música teatral en España. Barcelona: Labor, S.A., 1945, p. 124).

6. Compuesto de 23 hojas, sin numerar ninguna de ellas: portada + "Advertencia" (2) + "Personas" (1) + 19 de la obra propiamente dicha.

7. El Diario de Madrid, de 26 de enero de 1792, n. ${ }^{\circ} 26$, pp. 103a-103b, indicaba los puntos de comercialización: "Véndese en la entrada del mismo Coliseo, en la librería de Castillo, frente a las gradas de S. Felipe, y en la de Barco, carrera de San Gerónimo, su precio un real", aunque en este su anuncio de aparición de la obra padecía la equivocación -que ya prácticamente se convertirá en una constante- en el nombre masculino de su título: "Coriolano", probablemente por confundirse con el de la tragedia de Shakespeare. 
De todos modos, extraña tanta demora en autorizar su publicación, cuando la licencia para ser representada en el escenario había sido alcanzada con mucha mayor antelación. Así, con fecha 1 de julio de 1791 consta la aquiescencia de Lorenzo Ygual de Soria, inquisidor ordinario y vicario «de esta Villa de Madrid y su Partido", obrante en un manuscrito de la Biblioteca Histórica Municipal ${ }^{8}$, en donde aquel se pronunciaba en los siguientes términos:

Damos licencia para que el antecedente Dracma [sic] en verso castellano intitulado el valor y clemencia española, en América; se pueda representar en los teatros públicos de esta Corte; mediante que habiendo sido reconocido de manera ordinaria no se encuentra en él cosa que se oponga a materia [ilegible] Fe y buenas costumbres.

Así, Leandro Moratín, se la atribuye a García Malo con el rubro de Coriolano, en el Catálogo de piezas dramáticas publicadas en España desde el principio del Siglo XVIII hasta la época presente (1825). En Obras de Don Nicolás y Don Leandro Fernández de Moratín. Nueva edición; dentro de la Biblioteca de Autores Españoles desde la formación del lenguaje hasta nuestros dias. Madrid: Atlas, 1944, p. 331. En idénticos términos consta registrada por Ovilo y OTERO, Manuel. Catálogo Biográfico Bibliográfico del Teatro Moderno Español, desde el año 1750 hasta nuestros días, por D. - - BNM. Ms. 14616, tomo I, f. 432r. Similar, aunque no idéntico, error padece ARTEAGA, Joaquín de. Índice alfabético de comedias, tragedias y demás piezas del teatro español, formado por D. - . BNM, Ms. 14698, f. 163r.: "Glaura y Coroliano» (nueva designación), y se la asigna a Lidón; en f. 387r.: "Valor y clemencia española", sin atribución de autor. Igualmente, figura equivocado el nombre del protagonista masculino en el Catálogo del teatro lírico español de la Biblioteca Nacional. II. Libretos D-O. Madrid: Ministerio de Cultura, Dirección General del Libro y Bibliotecas, 1991, p. 132: "Drama heroyco en verso castellano, intitulado Glaura y Coriolano, puesto en música...». Del mismo modo, Jerónimo Herrera recoge también "Coriolano" en vez de "Cariolano" (Herrera Navarro, Jerónimo. Catálogo de autores teatrales del siglo XVIII. Madrid: Fundación Universitaria Española, 1993, p. 208). Tampoco acierta IGLESIAS DE SOUZA, Luis. El teatro lírico español (volumen II. Ensayo de catálogo: letras F-O. La Coruña: Excelentísima Diputación Provincial de La Coruña-1993, 1995. Volumen III. Ensayo de catálogo: letras P-Z. La Coruña: Excma. Diputación Provincial de La Coruña-1994, 1995. Volumen IV. Libretistas y compositores. La Coruña: Excma. Diputación Provincial de La Coruña-1996, 1996), en cuyo volumen II, p. 282, leemos: "Glaura y Coriolano», o en el III, p. 839: "Valor y la clemencia española con Glauca y Coriolano, El», errando también en el nombre de pila del autor del texto: "García Malo, José». Esa misma confusión, en cuanto a la denominación de los dos protagonistas, se echa de ver en el volumen IV, p. 205, así como en su p. 587, en la que, aunque aparece nuevamente bien anotado el de la protagonista femenina ("Glaura y Coriolano»), se consigna esto inmediatamente detrás: «Valor y clemencia española con Glauca y Coriolano, El».

8. Carnero, por su parte, remitiéndose a Carlos CAMBronero (Catálogo de la Biblioteca Municipal de Madrid. Madrid: Imprenta Municipal, 1902, p. 478), ya comentaba la existencia de dos manuscritos de esta obra en la Biblioteca Histórica Municipal de Madrid, con la signatura: 1-93-2, "de 11 y 10 folios, anónimos en texto y aprobaciones». Y reparaba el mismo Carnero que «en el ms. falta la Advertencia y se observan pequeñas e insustanciales diferencias en el texto; la mayoría de las acotaciones han sido acortadas, y algunas suprimidas, al imprimirse. Las aprobaciones eclesiásticas son de 1 y 7 de julio de 1791, y del 15 la de Santos Díez González» [CARNERo, Guillermo. "Estudio preliminar». En García MAlo, Ignacio. Voz de la Naturaleza (Lisandro y Rosaura. Teodoro y Flora. La desventurada Margarita. Amadeo y Rosalía. Flavio e Irene. Anselmo y Elisia. El brigadier y Carlota. El benéfico Eduardo). Selección, estudio preliminar y notas de Guillermo Carnero. Madrid: Editorial Támesis, S. L., 1995, p. 79 y pp. $79-80$, respectivamente]. 
Al otro día, 2 de julio, se ordenaba pasar la obra para su examen a fray Joseph de Puerta Polanco y al corrector Santos Díez González. Emitió su informe el primero de ellos el día 7 de julio ( $n o$ he hallado en el Cosa que pueda ser impedimento para que se permita su representación»). Y el día 19 (no el 15 como consigna Carnero), el censor gubernativo Santos Díez despachaba igualmente dictamen favorable en el que -a diferencia de los censores eclesiásticos, que circunscribían su calificación al terreno de la moral- entraba a valorar determinadas cuestiones técnicas, para ensalzarlas:

De orden del Sr. Corregidor, Juez Protector de Teatros, \&c. he examinado el presente Dramma [sic] en un Acto, intitulado El valor y clemencia Española en América, y le he hallado proporcionado por su lenguaje, y suave versificación para ponerse en Música, y servir de ensayo a otros Melodramas en Castellano.

Por fin, el 20 de julio de 1791 le fue otorgado el definitivo plácet para poder ser llevada a las tablas. Con anterioridad a aquel señalado jalón temporal de 2 de julio, con el que queda verificado el inicio del proceso de aprobación pública, existe constancia de que la pieza se hallaba ya escrita desde por lo menos varios meses atrás, y que incluso los actores habían estado preparando su representación. Tal se colige de una carta de Estala a Forner, firmada el 24 de mayo de 1791:

Se está ensayando la ópera seria compuesta por Malo, y puesta en soberbia música por Lidón: me parece que este drama (aunque débil) va a causar una sensación muy viva, y quizá va a formar época en nuestro teatro, arruinando el de la ópera, y abriendo los fundamentos para un teatro Lírico Español'

De ahí que, a cuenta de las fechas barajadas, tampoco ahora podamos coincidir con García Fraile en su conjetura relativa a que la ópera fue compuesta para ser representada en 1792, con motivo del trescientos aniversario del descubrimiento de América, puesto que como hemos visto la idea primitiva, truncada por la dilación en el veredicto del Consejo de Castilla, había sido la de estrenarla en el mes de julio de 1791.

Por otro lado, sí que es cierto que una vez obtenida la licencia de impresión la subida a las tablas fue cosa de pocos días; exactamente de cuatro, pues el Diario de Madrid (n. ${ }^{\circ} 24$, martes 24 de enero de 1792, p. 96) informaba, bajo el rótulo "Teatros", de su puesta en escena para esa misma noche, si bien con la desventurada y permanente característica de desacertar en el título, y ahora también además en el número de actos: «En el de la calle del Príncipe por la Compañía de Ribera,

9. «Veintiuna cartas inéditas de D. Pedro Estala dirigidas a D. Juan Pablo Forner, bajo el nombre arcádico Damon para la historia literaria del último tercio del siglo XVIII", por copia de Juan Pérez de Guzmán. Boletín de la Real Academia de la Historia, 1911, tomo LVIII, cuaderno I, pp. 5-36, p. 13. 
se representa una pequeña pieza en 2 actos, titulada La Araucana ${ }^{10}$, de música, con una introducción, una tonadilla y un fin de fiesta, todo nuevo, de Teatro".

Al día siguiente, el mismo diario (p. 100), además de darnos noticia de la continuidad en cartel de la ópera -pues emplea idénticas palabras que en la ocasión anterior-, reseñaba la recaudación lograda la noche previa, bastante digna por cierto: 6.699 reales. Igualmente, los sucesivos números del periódico van facilitando los respectivos ingresos del día precedente; así, el Diario de Madrid de 26 (5.867 reales, del miércoles), 27 (5.576 reales, del jueves), 28 (4.297, del viernes), 29 (3.851, del sábado), 30 (5.547, del domingo) y 31 de enero (3.369, del lunes). El Diario de Madrid del miércoles 1 de febrero (p. 128) consignaba la cantidad conseguida el martes: 3.143 reales, a la par que advertía de la representación de otra distinta comedia para ese día.

\section{PReCAutiones De Un ESCRITOR AVISADO}

Si bien, como queda de manifiesto, el ejemplar del drama salió del molde sin el nombre de su autor, pensamos que dicha omisión obedeció muy probablemente a una estudiada decisión del mismo. Pues no habría que rebuscar mucho en su pasado para encontrarnos con disposiciones de corte similar. Como, por ejemplo, cuando alumbró la tragedia Guillermo de Hanau, en donde asomaba únicamente con sus iniciales, y además parcialmente desfiguradas: D. I. M. S. (D. Ignacio Malo Sánchez $)^{11}$. Por no mencionar que los primeros volúmenes de su colección de novelas Voz de la Naturaleza fueron impresos con la identidad de un amigo suyo: Mariano de Anaya, y que no utilizó la suya propia hasta que comprobó el favor del que gozaban aquellos relatos suyos entre los lectores. De ahí que el temor ahora a un reto desconocido creemos que lo condujo de nuevo inexorablemente al anonimato.

Su gran vulnerabilidad, aún en aquella época, hacia los juicios de valor negativos para con sus escritos, originada acaso por unos sonetos, ciertamente mejorables, compuestos en su juventud, y tomados a chacota por diversos colegas

10. Distinta cuestión sería considerar si, en lugar de erratas, ambas alteraciones habían sido rectificaciones posteriores, realizadas tal vez por la compañía teatral. Andioc y Coulon en su recopilación de los dramas representados en Madrid recogen, junto a la denominación de "Glaura y Cariolano (El valor y clemencia española [en América] con Glaura y Coriolano [sic])» (p. 738), esta otra que vimos que aparecía en el Diario de Madrid: "Araucana, La (o Glaura)» (p. 632); y anotan también su representación el 24 de enero de 1792 en el teatro del Príncipe [vid. ANDIOc, René y Coulon, Mireille. Cartelera teatral madrileña del siglo XVIII (1708-1808). Madrid: Fundación Universitaria Española, 2008, volumen II, p. 901]. Sánchez.

11. Recordemos, al efecto, que su nombre entero era el de Ignacio María Antonio García-Malo 
de su círculo de amistades ${ }^{12}$, creemos que fomentaron en él la utilización de todo un repertorio de subterfugios con los que tratar de lograr la piedad de la crítica y paliar hipotéticos varapalos públicos ${ }^{13}$; costumbre, por otra parte, nada novedosa, pues muchos escritores del siglo fueron señaladamente devotos de los prólogos galeatos.

Entre todo ese tipo de estrategias, no podía omitir Malo en Glaura y Cariolano la singular circunstancia de estar ejerciendo prácticamente de precursor de un ambicioso proyecto ${ }^{14}$. Así es que, desde la ya mentada "Advertencia", nos concreta el autor la naturaleza de su «experimento», y la razón de pulsar dicha cuerda creativa. Todo ello envuelto en una capa de humildad y patriotismo:

Esta piececita es solamente un ensayo en nuestro idioma Castellano de la grande Ópera seria Italiana [...], únicamente con el objeto de demostrar que nuestra Lengua es capaz de las modulaciones de la Música, y que podemos aspirar a formar con el tiempo un Teatro Lírico, imitando a los Italianos, como han procurado hacerlo los Franceses, no obstante que su lenguaje ni es tan numeroso, ni armonioso como el nuestro ${ }^{15}$.

12. Su amigo Quintana rememoraba el asunto bastantes años después: "Unos cuantos humanistas frívolos y, lo que es peor, malos amigos suyos habían querido esparcir sobre él un aire de disfavor y tal vez de ridículo por la poca fortuna de sus trabajos poéticos" (QuinTAnA, Manuel José. Memoria sobre el proceso y prisión de D. - en 1814. En QuinTANA, Manuel José. Obras inéditas del Excmo. Señor D. - , precedidas de una biografía del autor [...]. Madrid: Medina y Navarro, Editores, 1872, p. 186).

13. No se le escapaba a García Malo que el omitir su nombre en el libro le valía, si acaso, para que el gran público no le vinculara con él; pero no así le resultaba solución ante otras gentes, a las que, por mor de su posición y relaciones, difícilmente se les escapaban los entresijos del Madrid literario, individuos generalmente bastante más entendidos en la materia que el general de los lectores o espectadores, y de quienes verdaderamente temía nuestro escritor el juicio.

14. Cierto es que en España, aunque no con asiduidad, sí que se habían cantado ya anteriormente óperas en castellano, a menudo confeccionadas para celebrar eventos de índole personal o familiar de miembros de la nobleza. Pero la diferencia esencial entre las piezas de esos compositores -algunos muy significados, como Sebastián Durón, Antonio Literes, José Nebra Blasco, etc.— y la iniciativa de García Malo y de Lidón residía principalmente en la voluntad por alcanzar ahora la consagración musical de la lengua hispana, y de llevarla a cabo de un modo sistemático; García Fraile, con el que ahora sí coincidimos, formula el asunto así: "No se trata por tanto de una producción musical forzada por la ocasión concreta, sino que obedece a un planteamiento de base: el idioma castellano, tan rico y armonioso como puede serlo el italiano, el idioma musical por excelencia, bien puede ser utilizado en la creación del Teatro lírico" (GARcía FraILE. "Un drama heroico en verso castellano", op. cit., p. 168)

15. Había sido costumbre hasta ese momento, desde los tiempos de D. Ramón de la Cruz, que una vez españolizada la letra se adaptara -tal y como apunta Subirá- el lugar de la acción, la nacionalidad de los personajes, o bien ambos particulares conjuntamente (vid. SubIRÁ, José. "Evocaciones en torno a las "óperas madrileñas"”. Revista de la Biblioteca, Archivo y Museo, enero de 1954, Año XXIII, n. ${ }^{\circ}$ 67, p. 102). Ha de reseñarse, al respecto, que por una Real Orden de 28 de diciembre de 1799 se prohibieron en España las representaciones operísticas en idioma extranjero. La razón, según anota Cotarelo, estribaba en que, a cuenta de sus muy elevados gastos -derivados esencialmente de los bailes pantomímicos ejecutados por un gran número de personas-, no podía subsistir sin grandes auxilios del Gobierno, o sin causar la ruina de los empresarios (vid. CoTARELO y Mori, Emilio. Orígenes 
Al hilo de estas últimas palabras de García Malo, hemos de destacar que, según se desprende de ese mismo preámbulo, la formulación de dicho tipo concreto de obra, a semejanza de las que se daban en Italia, habría que situarla en la "persuasión" de algún que otro encumbrado individuo -entre los que quizá se encontraba el conde de Floridablanca, antiguo embajador en Roma-, mecenas a quienes convenía siempre contentar: "Su fin ha sido agradar a varias personas amantes y protectoras de las buenas Artes, que han manifestado los mayores deseos de que se hiciese un ensayo de esta naturaleza» ${ }^{16}$.

Tornando al anterior asunto de la variedad de argucias manejadas por García Malo para granjearse la simpatía del receptor de sus textos, o cuando menos la clemencia de los doctos, constituía otro de los elementos de ese catálogo la propia modestia con la que designaba su elaboración artística, y ello desde el inicio mismo de la "Advertencia» que la precede: "piececita", o también a renglón seguido del título: "Glaura y Cariolano", que va estampado en el interior del libro: "pequeña pieza dramática»; procedimiento que había sido ya previamente utilizado, y de forma reiterada, ante los censores, empleando el término "operita", primero en su escrito petitorio a la Sala del Consejo de Castilla, de 6 de julio de 1791, y en el posterior a Escolano de Arrieta.

Otro de esos recursos, en los que se le ve pronto en servirse, es el de apelar directamente a la benevolencia del espectador: "Su más grata recompensa será la indulgencia del Público" ("Advertencia»), con la consabida razón, esta vez, de que había sido concebida para utilidad y gloria de la patria.

Ya unos años antes, había García Malo echado mano de una parecida colección de técnicas y excusas para mitigar los posibles reproches de los destinatarios de sus publicaciones. Así, por ejemplo, artes tales como el rehuir toda ínfula de vanidad, presentando su trabajo como un fruto imperfecto, a partir del cual otros más capacitados pudieran igualar o mejorar para España lo que ya existía en el extranjero, o el de implorar la benignidad del lector, se hallaban ya presentes en la "Dedicatoria" con que ofrendó al conde de Floridablanca su traducción de la Ilíada:

y establecimiento de la ópera en España hasta 1800. Madrid: Tip. de la Revista de Arch., Bibl. y Museos, 1917 , p. 402).

16. Ese reto había sido ya lanzado unos años atrás desde el Memorial literario (n. ${ }^{\circ}$ 38, febrero de 1787), periódico fundado, junto con Pedro Pablo Trullenc, precisamente por Joaquín Ezquerra, amigo que fue de García Malo, según ya hemos dicho, y censor de la obra. En el mencionado ejemplar podía leerse en un artículo, sin firmar, titulado "Teatros. Introducción» el siguiente comentario sobre la situación operística en España: «Los Italianos parece que se han arrogado el imperio de este género, y a la verdad, o sea preocupación, a [sic] sea que hasta ahora no se haya llegado en otras lenguas a competir la dulzura del lenguaje italiano, o el primor o valentía de su música, este punto se lleva el primer lugar; acaso podrán competir nuestra música y lenguaje en nuestra España, cuando se nos presenten, como se ofrece, Óperas Españolas; la conjetura no carece de fundamento, a vista de las zarzuelas, y otras piezas de música que se han representado ya en nuestros Teatros con aplauso» (p. 263). 
El deseo de emplear mis cortos talentos en utilidad de la patria [...], el reflexionar que mi arrojo podrá tal vez servir de estímulo a otros de mayores talentos, para que se animen a corregir mis defectos [...], creo pueden disculpar mi temeridad, y no hacerme indigno de la indulgencia del Público ${ }^{17}$.

Además, compartía Glaura y Cariolano con la traslación del poema de Homero la cualidad de ser en alguna medida obras pioneras en las letras castellanas; aquella en cuanto al propósito creativo, y esta en lo tocante al idioma, ya que fue, como repetidamente se encargará de proclamar su traductor, la primera versión íntegra de la Ilíada que salió de la imprenta en lengua española. Y en cuanto a un determinado aspecto que las diferenciaba, cual resultaba que la primera de dichas obras nació para ser cantada, no se olvida D. Ignacio de procurar en seguida disculparle las posibles carencias en dicha faceta: «Se esmerarán los Actores en desempeñar sus papeles, sin embargo de no ser profesores, ni estar acostumbrados a cantar composiciones de esta clase» ("Advertencia»).

No coincide, empero, esta apreciación -a no ser, que las concretas personas elegidas para representar aquella pieza fueran precisamente las más desentrenadas en dicho arte- con las siguientes observaciones de José Subirá: «Los actores madrileños -especialmente los de la compañía de Ribera, que poseía privilegiadas partes de canto- dieron en diversas ocasiones ópera italianas, con la mayor fortuna». Prosiguiendo un poco más adelante: "Esos actores hallábanse, pues, sobradamente preparados para empresas filarmónicas de gran altura, por el nivel de virtuosismo vocal que iba logrando la tonadilla escénica entonces a costa de un auténtico hispanismo» ${ }^{18}$.

Por otra parte, todo descargo podía parecer poco tratándose de un producto dramático-musical, frecuentemente desatendido, y por ello denostado por voces críticas autorizadas, caso de Moratín el Mozo, quien denunciaba, inmisericorde, en La comedia nueva o el café la actitud de dejadez y los modos descuidados con que se preparaba la música en el teatro, si bien dirigía en este caso sus mordaces apreciaciones hacia una clase de composición por completo alejada de la ópera ${ }^{19}$.

17. "Dedicatoria al Excmo. Sr. D. Josef Moñino, Conde de Floridablanca». En Homero. La Ilíada de Homero, traducida del griego en verso endecasílabo castellano por D. Ignacio García Malo. Madrid: Pantaleón Aznar, 1788, t. I, h. s. n. El rasgo de humildad en sus composiciones ya lo había sacado a relucir incluso antes, prácticamente desde los mismos inicios de su carrera literaria: "Esperando que algún otro de superior talento al mío, procurará aplicarse a perfeccionar este modo de hacer Tragedias y Comedias" (D. I. M. S. [D. Ignacio Malo Sánchez]. "Prólogo», sin paginar, al Guillermo de Hanau. Madrid: Blas Román, 1786).

18. Subirá. Historia de la música teatral en España, op. cit., pp. 121-122. Stoudemire, por su parte, apunta el hecho de que, si bien no en abundancia, existía gente capacitada para esos menesteres: "There were even a few actors who could sing rôles in operas» (STOUDEMIRE, Sterling A. "Metastasio in Spain». Hispanic Review, 1941, t. IX, n. ${ }^{1}$, January, pp. 184-191, p. 184).

19. "D. Eleuterio- Si se lo he dicho a usted ya. La tonadilla que han puesto a mi función no vale nada, la van a silbar, y quiero concluir esta mía para que la canten mañana.

D. Serapio- ¿Mañana? ¿Con que mañana se ha de cantar, y aún no están hechas ni letra ni música? 
Ese diálogo entre D. Serapio y D. Eleuterio, transcrito también por John Dowling, le permite efectuar a este la siguiente aseveración:

Aun en este trocito satírico, Moratín, al tratar el más ínfimo de los géneros líricos, expresa el prejuicio de la época: la letra vale poco, por cierto, pero la música vale menos [...]. El poeta es el artista reconocido, el músico queda en penumbra si no en el anonimato ${ }^{20}$.

Aunque de ninguna manera pretendemos equiparar este tipo de prácticas negligentes con el cualificado trabajo de Lidón -ni por supuesto la tonadilla con la ópera-, sí que tales argumentos nos hacen tornar, una vez más, a la discrepancia con García Fraile relativa a la personalidad del responsable último de la pieza, puesto que en modo alguno podemos dar por buenas sus palabras en favor de la persona que musicalizó la obra: "Reivindico para José Lidón ese breve pero denso Manifiesto de defensa del idioma castellano como idioma musical, apto para la composición del nuevo teatro lírico español» (p. 175).

Sin embargo, a la hora de adjudicar a una u otra figura el mérito (o demérito) del resultado final, conviene contextualizar, como hace Dowling y, retrotrayéndonos a la época en que surgió, distinguir entre el motor principal de la producción creativa ("El poeta es el artista reconocido») y los agentes auxiliares que participaron en ella, por grande que fuera la belleza que estos aportaran a la misma. En este sentido, no será ocioso recordar la terminología empleada en la propia "Advertencia", en la que paladinamente se distinguían las dos distintas funciones: "Los hombres de buen gusto e imparciales podrán juzgar si el Autor ha realizado su objeto, y si el Maestro de música ha sabido expresar en ella aquel sentimiento y elevación que corresponde a la acción».

Además, a través de unas palabras transcritas unas cuantas líneas antes que las anteriores, García Malo, a la vez que continuaba con esa su perenne cautela de anticiparse a las críticas negativas, dejaba clara constancia de que aquella tarea había sido fruto principalmente de un dramaturgo, y no de un músico, pues confesaba que la construyó «limitándola lo posible para que fuese corta, y pudiese cantarse por pocas personas, a fin de no fastidiar a los espectadores» ("Advertencia»). De ahí que solamente cuatro personajes tengan intervención vocal: Cariolano,

D. Eleuterio- Y aun esta tarde pudiera cantarla, si usted me apura. ¿Qué dificultad? Ocho o diez versos de introducción, diciendo que callen y atiendan, y chitito. Después unas cuantas coplillas del mercader que hurta, el peluquero que lleva papeles, la niña que está opilada, el cadete que se baldó en el portal; cuatro equivoquillos, etc., y luego se concluye con seguidillas de la tempestad, el canario, la pastorcilla y el arroyito. La música ya se sabe cuál ha de ser: la que se pone en todas; se añade o se quita un par de gorgoritos, y estamos al cabo de la calle» (FERnándEZ DE MORATín, Leandro. La comedia nueva o el café. Edición, prólogo y notas de Federico Ruiz Morcuende. Madrid: Espasa-Calpe, 1973, Clásicos Castellanos, I, 3, p. 13).

20. Dowling, John. "Ramón de la Cruz en el teatro lírico del XVIII, el poema y la música». En Sala Valldaura, Josep María (ed.). Teatro español del siglo XVIII. Lleida: Universidad de Lleida, 1996, vol. I, pp. 309-327, pp. 309-310. 
Glaura, Tegualda y D. Alonso de Ercilla, ya que los soldados españoles y los negros ejecutan su papel en silencio. Y aunque el propio Santos Díez González - profesor de Poética de los Reales Estudios y censor que había sido, precisamente, de esta pieza- expondrá en 1793 que «el Blanco de la Ópera es representar las pasiones humanas por medio de la Música y aparato teatral, o (lo que es lo mismo) por medio del interés y la ilusión ${ }^{21}$, lo cierto es que el artificio musical solía hallarse relegado a un segundo plano, pues el público, como apunta Stoudemire, se sentía, en realidad, atraído fundamentalmente por el argumento: "It is a matter of record that before the advent of Rossini the audience was more interested in the plot than in the music ${ }^{22}$.

Tal sentencia de Stoudemire no debe conducirnos a la conclusión, errada, de que el espectáculo operístico carecía de público en esa época; pues ahí están, en muestra de su aceptación, las numerosas representaciones, muchas de ellas traducidas del italiano, que -por circunscribirnos solamente a Madrid- se habían dado en el palacio del Buen Retiro y, más tarde, en los Caños del Peral. Lo que parece resaltar el referido Stoudemire es que los espectadores quedaban más seducidos por la intriga de la obra que arrobados con la hermosura del canto ${ }^{23}$. Justamente la misma opinión que mantenía García Malo, para quien la preferencia que, en términos generales, manifestaban los asistentes por el contenido del texto propiciaba que su soporte melódico quedara subordinado a este; al contrario, por cierto, de lo que acabó sucediendo luego.

\section{ADECUACIÓN DEL DRAMA HEROICO GLAURA Y CARIOLANO A LAS NORMAS DE LA TRAGEDIA NEOCLÁSICA ${ }^{24}$}

Para los ilustrados en general, y particularmente para García Malo, la especie teatral constituía una de las más útiles herramientas de cara al ejemplo, al fomento de las virtudes y, en definitiva, a la mejora del ciudadano y de la sociedad, puesto que a su través, y so capa de divertimento, el espectador era susceptible de adquirir una serie de enseñanzas y valores muy difíciles de imbuirle de otro modo ${ }^{25}$.

21. Díez GonZÁLEZ, Santos. Instituciones poéticas. Madrid: Benito Cano, 1793, p. 173.

22. StOudemire. "Metastasio in Spain", op. cit., p. 184.

23. De ahí la importancia de poder tener acceso a una versión de la obra en castellano, aun cuando se careciese de una adaptación hispana previa: «Even when the original Italian was sung, bilingual texts were available, in order that the public might follow the plot more easily" (STOUDEMIRE, ibidem).

24. Acerca de las similitudes entre uno y otro género literario, apunta Sala Valldaura: "Las tragedias neoclásicas españolas sobre la conquista de América se relacionan muy estrechamente con los dramas heroicos que tratan el mismo tema" (SAla VAlldaura, Josep María. De amor y política: la tragedia neoclásica española. Madrid: Consejo Superior de Investigaciones Científicas, 2005, p. 390).

25. Con razón podrá decir el Correo de Madrid de 23 de abril de 1788, p. 875b: "No será pues avanzar demasiado, si se quiere añadir que el teatro es la escuela más pública donde con pretexto de recreo concurre todo el pueblo sin distinción de clases ni estados». 
Por ello, «inspirar buenas ideas» era para nuestro autor «el único fruto que debería sacarse del Teatro», en el que convendría representar asuntos "que enseñasen a los hombres a vivir honestamente, y que inspirasen horror, y aborrecimiento a la traición, a la venganza, al rencor, y a las demás inicuas y vergonzosas pasiones, que los arrastran a cometer atentados, y maldades ${ }^{26}$.

Testimonio de ese punto de vista lo reiterará en 1794 por medio del prólogo a su traducción de Pamela Andrews, donde, a pesar de convertir al castellano una novela, no dejará de reconocer las ventajas de la representación escénica, especialmente a efectos de promover la integridad moral: "Cierto no sé qué dulce y agradable que se introduce en el corazón humano después de la representación de una acción virtuosa, heroica y magnánima; y finalmente, una especie de emulación santa en cada espectador de ser Pamela» ${ }^{27}$.

Exactamente igual le oiremos proclamar a la altura de 1803; esta vez dentro de la ficción del relato, por medio de su última novela: El benéfico Eduardo, en donde endosa sus propias teorías a Eduardo, el ejemplar protagonista del libro, y trasunto del propio autor ${ }^{28}$ : "Creía que el Teatro no debía ser sino la escuela de las costumbres públicas y privadas, y que todo cuanto se representase en él, que pudiese inspirar a los hombres sentimientos honestos, magnánimos y virtuosos ${ }^{29}$.

Ahora bien, para alcanzar tan meritorios fines, no valía con escribir lo primero que al dramaturgo le viniese a la péndola, ni -buscando el mero provecho material- ${ }^{30}$ agasajar al espectador con todo un abanico de recursos que se sabían de su agrado; sino que, por contra, lo que la doctrina neoclásica proponía, especialmente centrándose en la tragedia, «sin disputa el género predilecto de los

26. García Malo, Ignacio. "Prólogo" a Doña María Pacheco, mujer de Padilla. Tragedia española en tres actos. Madrid: Viuda de Miguel Escribano, 1988, h. s. n. García Malo, como se ve, comulgaba plenamente con la doctrina expuesta medio siglo antes por Luzán: «Sabemos también cuánta fuerza tiene sobre nosotros el ejemplo ajeno. Por esto al ver en las tragedias cuántas inquietudes cuántas miserias y pesares acarrea consigo una violenta pasión, un desordenado apetito, hará los oyentes más cuerdos y más moderados en sus afectos por el miedo de incurrir en semejantes desgracias» [LuZÁN, Ignacio de. La poética o reglas de la poesía en general y de sus principales especies. Primera edición completa de ambos textos dieciochescos (1737y 1789). Edición, prólogo y glosario de Russell P. Sebold. Barcelona: Editorial Labor, 1977, p. 491].

27. García Malo, Ignacio. "Prólogo del traductor". En Richardson, Samuel. Pamela Andrews o la virtud recompensada. Citamos por la 2. ${ }^{a}$ edición: Pamela Andrews o la virtud premiada. Madrid: Imprenta Real, 1799, t. I, p. V.

28. Vid. Rodríguez Morín, Felipe. "El matrimonio desigual en la obra de Ignacio García Malo: ¿un reflejo de su propia biografía?». En LORENzo Álvarez, Elena de (coord.). La época de Carlos IV (1788-1808). Actas del IV Congreso Internacional de la Sociedad Española de Estudios del Siglo XVIII. Gijón: Ediciones Trea, 2009, pp. 975-990, pp. 984-985.

29. García Malo, Ignacio. El benéfico Eduardo. Madrid: Imprenta de Aznar, 1803, p. 37.

30. Como tal hacía «una turba de copleros famélicos, que no se proponen en sus composiciones otro objeto, que el sórdido y mezquino interés" (EsTALA, Pedro. "Discurso preliminar". En ARISTÓFAnEs. El Pluto, comedia de Aristófanes, traducida del griego en verso castellano, con un Discurso preliminar sobre la comedia antigua y moderna. Por Don-, presbitero. Madrid: Sancha, 1794, p. 44). 
teóricos ${ }^{31}$, era que el autor tuviera que sujetarse a una serie de principios, no arbitrarios ni artificiosos, sino inherentes al mismo hecho teatral, encaminados siempre a lograr que el público pudiera creerse aquello que estaba presenciando. Así fue que la verosimilitud se erigió en la piedra angular del entramado: en «la regla de las reglas», según frase de Nicolás Moratín ${ }^{32}$.

Por eso García Malo se encargará en seguida de proclamar en la "Advertencia» de su ópera la observancia de tan capital principio: «diversificando los lances según se ha creído más verosímil».

Y desde luego que las coincidencias entre esta pieza de Malo y la tragedia neoclásica no se quedaron ahí. Así, había advertido Luzán, como uno de los detalles para no romper esa suerte de ensoñación o de total inmersión del público con lo que estaba contemplando, y a fin de que nada de lo que viera u oyera le pareciera discordante con la realidad, la conveniencia de elegir los temas «difuminados» en la lejanía, bien espacial, o bien temporal:

Porque los hechos muy recientes se saben con más individualidad [...]. Todo esto es embarazo y estorbo para que el poeta pueda variar las circunstancias y los nombres y adaptar el hecho al teatro y a lo verosímil. Por lo cual debe siempre echar mano de historias y acciones antiguas y apartadas de nuestra edad (op. cit., p. 455).

El mismo García Malo, obediente y atento a los cánones, había ya, en su "Prólogo" a la tragedia Doña María Pacheco, observado el exacto seguimiento de tal precepto: "La opinión más común entre los Maestros del Arte Dramática es que el asunto para la Tragedia debe tomarse de un hecho histórico»33. De nuevo cumplirá ahora D. Ignacio con la poética neoclásica, y por partida doble, pues no solo elige un asunto acaecido más de doscientos años atrás, sino también geográficamente muy lejano.

De otra parte, fue objeto de la mayor consideración en ese código dramático, en atención a sujetar los impulsos del creador literario para que no se desviase del objetivo tan ansiado de la verosimilitud, el acatamiento de la regla de las tres

31. Álvarez Barrientos, Joaquín. "La teoría dramática en la España del siglo XVIII». Teatro (Revista de Estudios Teatrales). Las teorias teatrales, junio de 1992, n. ${ }^{\circ}$ 1, pp. 57-74, p. 67.

32. Moratín, Nicolás Fernández de. Desengaño II al Teatro español, sobre los Autos Sacramentales de Don Pedro Calderón de la Barca: su autor Don_, s. 1., s. a., sin impresor, p. 21 (a pesar de haber sido vendidos sueltos estos Desengaños, en el texto por el que citamos -Biblioteca Nacional de Madrid, T-10531- comienza la paginación por el primero y concluye en el tercero).

33. Cañas Murillo comenta lo siguiente sobre la tragedia neoclásica: «Los argumentos deben ser históricos, aunque los hechos que en ellos se incluyen no necesariamente han de ser tomados de la realidad. Pueden ser inventados, pero situados en épocas del pasado, no en la realidad contemporánea. Con ello se evita el apasionamiento que produce en el espectador la contemplación de acontecimientos temporalmente próximos a él» [CAÑAS Murillo, Jesús. "Sobre la poética de la tragedia neoclásica española». Filología y Lingüística, 1999, XXV (1), pp. 115-131, p. 118]. 
unidades, en especial la de acción ${ }^{34}$. Sobre este particular, había dejado asentado Aristóteles que "debe ser la acción una e íntegra»" Y eso mismo nos viene a sintetizar García Malo en la "Advertencia" de la pieza que nos ocupa, cuando recalca que ha acomodado sus lances "para hacer una acción completa y de algún interés».

Guarda Glaura y Cariolano, igualmente, la unidad de lugar, puesto que la peripecia transcurre enteramente en un mismo enclave, según precisa una acotación que antecede a la obra: "La Escena se representa en las inmediaciones de Arauco"; aunque con un doble asentamiento, ya que las cinco primeras escenas (I-V) acontecen en una "selva umbrosa adornada de árboles frondosos, robustas encinas [...]», y las tres últimas (VI-VIII): "En la misma selva umbrosa», en la que "por una parte se descubrirá una montaña eminente [...]; y por la otra se divisará [...] a lo lejos el acampamento del Ejército Español».

Por lo que atañe al encuadre temporal, ha de significarse su absoluta subordinación a la norma, puesto que los hechos suceden en el mismo día, y prácticamente se desarrollan en idéntico tiempo al que dura la representación.

Otra sujeción a las pautas neoclásicas lo constituye la circunstancia de que en esta composición dramática confluyen pocos personajes en escena, es más, solamente cuatro de ellos tienen intervención vocal en el total de la misma ${ }^{36}$. También se amolda a las leyes del arte el hecho de que los episodios violentos o encarnizados se producen fuera de la vista de los espectadores, a fin de ahorrarles una hipotéticamente brusca alteración del ánimo. De ahí que se deje sin mostrar cómo Cariolano da muerte con sus flechas a dos de los cuatro negros que habían atacado a su esposa Glaura y a la hermana de esta, Tegualda ${ }^{37}$.

Sin salirnos de este último punto, es menester precisar que si bien lavar el honor era en la tragedia neoclásica fruto de la venganza, y solía desembocar en conflictos políticos y de Estado, "sin embargo, hay ocasiones -como apunta Berbel Rodríguez- en que las circunstancias de la acción trágica confieren al honor y la

34. De este respeto por los mandamientos dramáticos neoclásicos también nos había hablado García Malo ya en 1786, con palabras referidas a su tragedia Guillermo de Hanau: «No pretendo persuadir que no tendrá algunas imperfecciones (porque sería casi la primera que no las tuviese) solo si presento este ensayo, para observar rígidamente las tres unidades» ("Prólogo», op. cit.).

35. ARIstóteles. Poética. Versión directa, introducción y notas de Juan David García Bacca. Caracas: Ediciones de la Biblioteca de la Universidad Central de Venezuela, 4. ${ }^{a}$ edición, 1982, p. 115. En muy similares términos, se había mostrado LuZÁn: «Todas las acciones esenciales de un poema o de una tragedia o comedia han de ir a parar y unirse en el fin y conclusión de la fábula» (op. cit., p. 458).

36. Cañas Murillo anota al propósito: «La inclusión de los personajes en las escenas se hace también con especial cuidado de evitar la acumulación. Es, también, consecuencia del respeto a la preceptiva neoclásica que recomienda no incluir más de cuatro personajes en las tablas y evitar que, incluso en esos casos, hablen a la vez más de dos o tres de ellos» (CAÑAs Murillo. "Sobre la poética de la tragedia neoclásica española”, op. cit., p. 121).

37. SANTOS DíEz formula el asunto de la siguiente manera: «En cualquiera clase de Tragedia se debe huir de presentar a vista de los espectadores en el teatro escenas atroces, y sanguinarias que los horroricen» (Instituciones poéticas, p. 105). Y algo más adelante añade: «Nunca será bien hecho el herir o matar atrozmente a vista de los espectadores» (p. 106). 
venganza connotaciones de reivindicación justa y acorde con la razón y la virtud». En este sentido, la mentada actuación de Cariolano frente a los negros podría suponer una especie de dignificación social del indio, puesto que, como, acto seguido de lo anterior, observaba Berbel: «En estos casos, el honor formaría parte de los atributos inherentes a la dignidad de toda persona y su defensa equivale a una justa y necesaria reivindicación ${ }^{38}$.

Otro requisito que mencionaba Luzán (op. cit., p. 510) para ajustar los dramas a las normas del arte era el del verso, en el que juzgaba que había de escribirse la tragedia, por resultar vehículo más apropiado que la prosa en cuanto al tono de elevación que merecía aquella; resaltando, a la vez, su preferencia por la rima asonante, aunque sin descartar la consonante, ya que no era ella del todo inverosímil según su parecer. A este respecto, hemos de señalar que la fábula, objeto de nuestro estudio, se nos presenta, como ya el título definitivo anticipaba, íntegramente compuesta "en verso castellano", siendo este predominantemente libre y de arte menor, sin excluir algún que otro endecasílabo; carentes todos de un patrón estrófico concreto, se limita el autor, todo lo más, a intercalar frecuentes pareados con rima consonante ${ }^{39}$.

\section{FinALIDAD PATRIÓTICA DEL MELODRAMA}

Por lo que atañe a la génesis de Glaura y Cariolano, no podemos descartar que su origen mismo no estuviese de algún modo relacionado con la admiración enorme que sentía D. Ignacio por las óperas de Metastasio ${ }^{40}$. Una profunda devoción que nos participaba Moratín con ironía cuando en una carta a Forner, fechada el 25 de abril de 1792, relataba de nuestro autor lo siguiente: "Altamente persuadido de la bondad de sus obras hechas y por hacer y hablando eternamente

38. Berbel Rodríguez, José J. Orígenes de la Tragedia Neoclásica Española (1737-1754). La Academia del Buen Gusto. Sevilla: Universidad de Sevilla, 2003, p. 193.

39. La formación humanística de García Malo se echa de ver en algún que otro escape lírico que nos trae a la memoria a san Juan de la Cruz o a Garcilaso: « Oh aves piadosas! / ¡Oh selva amiga! / Plantas hermosas, / ¿No hay quien me diga / Donde a mi esposo / Podré encontrar?» (escena 1, Glaura buscando a su amado); "La noche oscura / Se va acercando" (escena 6, Tegualda); «[...] caras prendas / de mi alma afligida [...]» (Cariolano, escena 4).

40. Andioc, incluso, en un principio la calificó de traducción del abate italiano: «Ignacio García Malo, autor de la tragedia $D^{a}$ María Pacheco (1788), traductor de la Ilíada (1788), y de dos óperas de Metastasio, Demofoonte y Coriolano" (Fernández de Moratín, Leandro. Epistolario de -. Edición, introducción y notas de René Andioc. Madrid: Castalia, 1973, p. 134, nota 9). Los mismos errores de adscribir la obra a una traslación de otra de Metastasio, y de llamar Coriolano al protagonista, los había padecido ya Menéndez Pelayo (vid. Menéndez Pelayo, Marcelino. Biblioteca de traductores españoles. Edición preparada por Enrique Sánchez Reyes Santander. Santander: Aldus, S.A. de Artes Gráficas, 1952, vol. II, p. 123. 
de Metastasio» ${ }^{41}$ (Epistolario, p. 133). Y qué mejor acicate para García Malo que emular a su idolatrado escritor alumbrando una ópera propia.

Distinta cuestión hubo de ser en aquellos momentos previos al nacimiento de la misma el asunto a tratar en ella, que terminó finalmente decantándose por la descripción, a través de un par de breves lances, de una disputa violenta entre unos indios araucanos y unos atacantes negros, y de la ulterior intervención de varios soldados hispanos destacados en la zona, en los alrededores de Arauco, en el Chile de los tiempos de Alonso de Ercilla ${ }^{42}$. De ahí que ese escrupuloso cumplimiento de las reglas neoclásicas -que más atrás hemos ido anotando- se hallara muy probablemente encaminado a que el contenido que se proponía transmitir el autor calase en el público con el mayor grado de eficacia posible. En el caso presente creemos que el mensaje a transmitir era el de la nobleza, valentía y magnanimidad del ejército y, por ende, del pueblo español.

A este propósito, no resultará ocioso recordar que unos años antes, durante el reinado de Carlos III, habían aflorado una serie de tragedias de índole colonial, fruto principalmente de las dos causas que pone de relieve Sala Valldaura: «Una es la general animadversión en Europa por el colonialismo hispano [...]. Otra segunda causa o circunstancia, de mayor entidad si cabe, se debe a los sucesos que estaban ocurriendo en ultramar ${ }^{43}$. Y remite para estos últimos a las palabras de Mendoza Fillola respecto de que es la época en la que se reconoce la independencia de los Estados Unidos, o en el convencimiento del conde de Aranda de que "la América meridional se nos irá de las manos" ". Unas líneas después, prosigue el mismo Mendoza Fillola:

En tal situación pareció oportuno alegar la justificada y necesaria labor de colonización hecha por España, para que sirviera de recordatorio de los deberes que, como vasallos de la corona española, debían mantener los criollos, con el fin de revitalizar el compromiso colonial.

De otra parte, por las autoridades (a cuyo socaire de alguna de sus instancias más altas - probablemente del conde de Floridablanca, tal y como ya hemos dejado consignado- había brotado la idea) tampoco estaría mal visto el que, en

41. En 1791 había García Malo realizado una traducción del Demofoonte (El Demofoonte del Ab. Pedro Metastasio [...]. Con el título del Inocente usurpador. Madrid: Benito Cano), que a finales de setiembre subió a las tablas en el Príncipe por la Compañía de Ribera. Entre otras ulteriores representaciones, se llevó a cabo una de ellas quince días antes que la ópera que nos ocupa (del 7 al 10 de enero de 1792), en el mismo teatro y por idéntica compañía de actores.

42. Como es sabido, a mediados del siglo XVI tuvo inicio un larguísimo conflicto bélico entre los conquistadores españoles y los indios que habitaban aquella zona, dando lugar a la denominada guerra de Arauco.

43. Sala Valldaura, De amor y política, op. cit., p. 391.

44. Mendoza Fillola, Antonio. "El compromiso colonial y el despotismo en la tragedia neoclásica». En Coloquio Internacional sobre el teatro español del siglo XVIII. Abano Terme: Piovan Editore, 1988, pp. 267-287, p. 282. 
aquellos tiempos peligrosos y nuevos en los que la Revolución francesa había terminado provocando el establecimiento de una barrera que se pretendía impenetrable entre la Península y el país vecino, se eligiese un tema tan propiamente español, como era el de las conquistas hispanas en ultramar, y tan convenientemente alejado de todos aquellos avatares europeos.

La acción de la obra, desarrollada en un único acto, que como ya antes quedó reseñado transcurre en una selva próxima a Arauco, nos informa de una doble escaramuza: la primera de ellas, nacida del hostigamiento a Glaura y Tegualda, dos hermanas indias de alto linaje, por parte de cuatro negros, que finaliza con la llegada de Caroliano, marido de Glaura, quien pone en fuga a todos los agresores (poco después, y por boca del propio Cariolano, sabremos que dio muerte a dos de ellos). El segundo lance tiene lugar a continuación, al ser apresado el valiente protagonista, cuya generosa liberación surge al cabo sin motivación alguna, solo por la imploración de Glaura al capitán Ercilla.

Ambos episodios, yuxtapuestos, creemos que contribuían poderosamente a ensalzar el poderío español, quedando potenciado este por el contraste evidente entre la victoria inicial del indio frente a una fuerza numéricamente superior, representada por los cuatro atacantes de las mujeres, y su posterior pugna con los españoles, que bien sencillamente, sin esfuerzo ninguno, lo apresaron.

Ha de recordarse, en este punto, que, como el propio autor reconocía: "su argumento está tomado de un pasaje de la Araucana de D. Alonso de Ercilla "45 ("Advertencia»). No obstante, existen elocuentes diferencias entre una y otra producción, fruto ello de la intención pretendida por García Malo de resaltar, por lo directo y breve, las glorias de España y de encarnarlas en sus soldados ${ }^{46}$.

De esta manera, si en el poema de Ercilla el indio Cariolán es apresado por los españoles gracias a una especie de pacto que cierra con su oficial, pues no son capaces a reducirlo luchando: "Tanta fue la destreza, tanto el arte / del temerario bárbaro araucano, / que no fue el gran tropel de gente parte / a que dejase un solo paso el llano" ${ }^{47}$, en la ópera de Malo, por el contrario, Cariolano se doblega

45. Las más significativas concomitancias entre ambas composiciones son puestas de manifiesto por Guillermo CARNERO en su ya mencionado "Estudio preliminar" a la edición de la Voz de la Naturaleza, de Ignacio García Malo: "La historia de Tegualda, de la cual solo aprovechó García Malo el nombre, se halla en Araucana, 2. ${ }^{a}$ parte, canto 20 octavas 25-79, y canto 21 oct. 1-12. El canto 28 de la misma 2. ${ }^{a}$ parte, octavas 3-52, contiene la historia de Glaura y Cariolán. Utiliza García Malo la genealogía de Glaura, su mal encuentro con los negros y la intervención, prisión y liberación de Cariolán: especialmente las octavas 7, 23-28, 31-45" (p. 80).

46. Aguilar Piñal apuntará a la sazón sobre el teatro neoclásico y su afección por los temas patrios: "Tragedias que evocan el pasado heroico nacional, la España que los ilustrados pretendían restaurar» (CADAlSO, José. Solaya o los circasianos. Edición, introducción y notas de Francisco Aguilar Piñal. "Introducción biográfica y crítica». Madrid: Clásicos Castalia, 1982, p. 31).

47. Ercilla, Alonso de. La Araucana, II. Edición, introducción y notas de Marcos A. Morínigo e Isaías Lerner. Madrid: Castalia, 2. ${ }^{a}$ edición, 1987, tomo II, p. 248. 
inmediatamente después de ser apuntado con un fusil, con lo que se suprime por completo la sensación de impotencia de la tropa:

¡Ay! Cariolano...

Ya todo lo has perdido.

A tus pies ¡oh Español! estoy rendido (escena 5).

Del mismo modo, ahora el capitán español, Alonso de Ercilla, dejará en libertad a Cariolano, a su esposa, Glaura, y a Tegualda, hermana de esta, sin razón ninguna, y a los solos efectos de resaltar «la humanidad» del militar hispano:

¡Oh Español valeroso!

¡Oh corazón piadoso!

¡Oh Capitán benigno! ${ }^{48}$,

cuando en La Araucana aquella merced se debía al agradecimiento, porque Cariolán, a riesgo de su vida, había propiciado la huida de su amo en una emboscada de los indios ${ }^{49}$.

Por otro lado, ha de quedar subrayado el hecho de que a través de los 337 versos que conforman la pieza hemos encontrado nada menos que catorce menciones al ámbito conceptual de la voluble fortuna, once de las cuales para increparla por su crueldad y rigor $^{50}$. Los cuatro personajes principales se refieren a ella en algún momento, siendo Glaura con siete alusiones quien se lleva en este campo la palma. Curiosamente, y como buscando el autor una especial significación en ello, en las dos únicas oportunidades que menciona este tema de los hados el capitán español, que son, por otra parte, las dos últimas veces que se pronuncian en escena, adoptan ambas declaraciones un contenido positivo ${ }^{51}$.

Como obra concebida para propaganda de la metrópoli, los personajes españoles que en ella aparecen, especialmente este predominante del capitán, resultarán

48. Ibidem, escena 8. Cada verso pertenece a un distinto personaje: Glaura, Tegualda y Cariolano, respectivamente.

49. Igualmente, omite el escritor ilustrado las pretensiones suicidas que, causadas por una suerte adversa, asaltaban a la Glaura de Ercilla: «muchas veces propuse de matarme, / mas por torpeza y gran maldad tenía / que aquel dolor en mí tan poco obrase / que a quitarme la vida no bastase» (op. cit., p. 246); sustituyéndolas por el más literario y menos peligroso "remedio" de solicitar la muerte a un tercero: "Concede a mis ruegos y a mi llanto / El único consuelo que me queda; / O si no dadme muerte, / Con esto tendrá fin mi infausta suerte» (escena 8).

50. Cañas Murillo aduce sobre el tema: «El destino se convierte en muchos casos en el justificador de los sucesos. Se une al tema de los cambios de fortuna. Puede ser el responsable del final trágico de los personajes. Tiende siempre a racionalizarse, no a convertirse en la fuerza ciega que figura en la tragedia clásica” (op. cit., p. 126).

51. La otra ocasión en la que aparece con sentido favorable es la que manifiesta Glaura, tras comprobar que su esposo había salido indemne de su persecución a los negros: «¡oh qué dichosa suerte!» (escena 4). 
ser portadores de las más variopintas virtudes, así como dueños de una cualidad muy valorada en la época: la sensibilidad. Un atributo de naturaleza tan excelsa que por sí solo parece bastarse para remediar muchas de las inclemencias del caprichoso fatum. Y es precisamente de ese contexto del que surgen las dos mencionadas referencias del oficial hispano al poder del destino, pues escuchando las imploraciones de Glaura para que deje libre a Cariolano responderá a esta así: «Cuánta piedad me causa / Vuestra angustia y dolor! Mi pecho siente / Con vosotras también vuestra amargura. / Quisiera remediar los infortunios / Que agravan vuestra suerte» (escena 8). Y por si ello no bastara, acto seguido pone en libertad a Cariolano con las siguientes palabras: "Mitigad esa pena que os afana, / No penséis que yo tengo alma inhumana. / No a unas fieras intratables / Las estrellas os entregan, / Sino a hombres que veneran / La sagrada humanidad (VIII).

La forma benigna y favorable en la que, gracias a la voluntad del militar, se resuelve el problema para los nativos les moverá a efectuar la aclamación, a coro, de la grandeza de España y de sus monarcas; repitiendo, a modo de catecismo, las palabras que el conquistador va pronunciando:

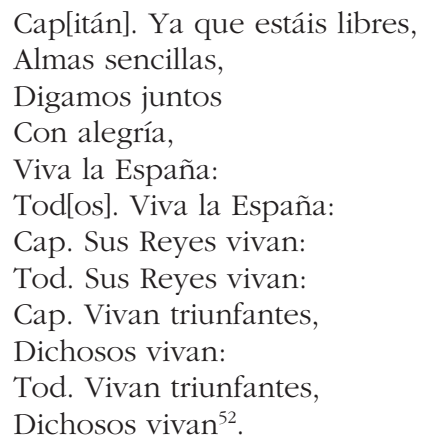

Talante patriótico este que, según expusimos, había constituido la finalidad de la ópera («demostrar que nuestra Lengua es capaz de las modulaciones de la Música»), y que se explicitaba más rotundamente en el título primigenio: El valor y Clemencia española en América con Glaura y Cariolano, que parecía sintetizar mucho mejor el contenido de la pieza.

Aunque desconocemos por entero las razones de su cambio, tal vez tuvieran algo que ver en ello consideraciones de índole comercial, pues cierto sí es que resultaba la etiqueta «drama heroico» de más tirón entre gran parte del público

52. En consonancia con lo que comenta Sala Valldaura: «En las tragedias sobre la conquista de América, la defensa de la actuación religiosa e imperial en el siglo XVI se identificaba igualmente con la estima de lo español, en general, y con la apología de su monarquía, en particular» (SALA VALLDAURA. De amor y politica, op. cit., p. 393). 
potencial, habida cuenta de que en ellos solían acontecer continuas aventuras de asunto nacional llevadas a cabo por adalides insignes de la patria ${ }^{53}$. Al hilo de todo esto, podríamos elucubrar (solo eso) acerca de que su primitiva denominación fuera un simple y pasajero rótulo, adoptado de forma provisional con el exclusivo fin de que no se espantasen o prejuzgasen en su contra aquellos que debían otorgar a la obra el visto bueno previo a su difusión.

Sin embargo, quizá fue la filiación a ese género lo que acabó finalmente por ocasionarle alguna que otra importante contrariedad, como por ejemplo su inclusión en la "Lista de las piezas dramáticas, que conforme a la Real Orden de 14 de enero de 1800, se han recogido prohibiéndose su representación en los teatros públicos de Madrid y de todo el Reino", nómina que antecedía al Teatro Nuevo Españo ${ }^{54}$. Y es que, aunque enteramente arreglada al arte, según hemos constatado, el apellido "heroica» tal vez terminó por perjudicarla en su credibilidad; puesto que precisamente el anónimo redactor de las páginas introductorias a dicho compendio dramático (¿Santos Díez González?) consignaba la siguiente advertencia: "Ni tampoco [lograrán un lugar distinguido en nuestro teatro] las Comedias que llaman Heroicas, y otras cuya materia son sitios y tomas de Ciudades, \&c. ${ }^{55}$.

\section{CONCLUSIÓN}

Ignacio García Malo, notorio y fiel seguidor de las reglas neoclásicas en la dramaturgia, escritor plenamente convencido de que no había mejor escuela de costumbres, ni cauce más eficaz para conmover y elevar los ánimos, fomentar las normas de la buena ciudadanía y consolidar los fructíferos efectos de una armoniosa convivencia, que los proporcionados por ministerio del teatro, no podía permitirse el descuido de que subiera a las tablas una pieza suya, como fue el caso de Glaura y Cariolano, sin que aflorasen en ella toda aquella suerte de elementos y resortes que en la época se reputaban de necesarios para alcanzar los fines propuestos. Artificios estos nada fáciles de conseguir fuera del gremio de los literatos, y aun causa perdida para muchos del propio oficio.

53. Ivi McClelland efectúa la siguiente observación sobre el particular: «En realidad no hubo drama heroico digno de su nombre en el dieciocho que no tuviera por lo menos una batalla íntegramente desarrollada en escena por uno o varios de los héroes nacionales, ya que el típico auditorio -al igual que Mr. Johnson en The Rehearsal- adoraba "aquellas obras en las que se herían y acuchillaban unos a otros en el escenario durante horas enteras" (MCClelland, I. L. "Pathos" dramático en el teatro español de 1750 a 1808. Traducción a cargo de Fernando Huerta Viñas y Guillermina Cenoz del Águila. Volumen II, La tragedia menor. Liverpool: University Press, 1998, p. 234).

54. Teatro Nuevo Español. Madrid: Benito García y Compañía, 1800, t. I, p. XXVI: «El valor y clemencia Española con Glaura y Coriolano [sic]. Curiosamente no se la consigna con el título definitivo de "Drama heroico», sino con el previo, el utilizado en su paso por la censura.

55. "Al lector». En Teatro Nuevo Español, op. cit., p. XIX. 
Es por todo ello por lo que en modo alguno puede plantearse la adscripción de esta obra a José Lidón. Interpretar la función de García Malo como la de mero libretista $^{56}$ de aquel, conforme apunta García Fraile, se nos antoja tan lejano a la realidad como, por poner solo un ejemplo, calificar de lo mismo a Antonio García Gutiérrez al escribir El trovador -representado, por cierto, también en el Príncipe-, drama romántico, acogido con delirio por la multitud, a partir del cual Verdi compuso la célebre ópera homónima unos cuantos años después.

A mayor abundamiento, tampoco puede obviarse el hecho de que algunas de las premisas que sustentaban esta creación artística en nada se avenían con las pretensiones propias de un músico, pues precisamente había procurado el dramaturgo "que fuese corta", con el propósito de que, por miedo a causar tedio en el público, no se prodigara mucho en melodías, esto es, que "pudiese cantarse por pocas personas, a fin de no fastidiar a los espectadores" (Advertencia»). Y no bastante, bien claramente se dejaba aviso en la "Advertencia" de que uno había sido el "Autor» del trabajo, y otro el «Maestro de música»"

Por último, hemos de recalcar que si el punto de partida de esta iniciativa literaria había sido el prestar un servicio a España, encomendado en principio a reivindicar que el idioma castellano resultaba tan capaz como el que más para «las modulaciones de la Música", el siguiente paso, en esa voluntad patriótica, consistió en seleccionar un episodio del pasado -lejano, según prescribía el dogma neoclásico- que pudiese ser aprovechado para ese tan idealista propósito. A tal fin eligió García Malo un fragmento de nuestra historia con el que poder ensalzar las glorias hispanas en América, y remarcar, de paso, el carácter sensible y virtuoso de los españoles, justo cuando parecía que comenzaban a atisbarse algunos síntomas inquietantes en aquellas colonias, susceptibles de poner, en un futuro, en peligro su unión con la Península.

Con la idea, quizá, de tranquilizar a la ciudadanía e infundirle ánimos e ilusión, especialmente por medio de su final apoteósico -en el que, sin duda, los efectos musicales debieron contribuir a potenciar notablemente la emoción en los espectadores y a fijar la grandeza de España más permanente en su memoria-, se atrevió Ignacio García Malo, en su sempiterno compromiso como escritor, guiado por unas

56. Utilizamos aquí este vocablo, si no en el más específicamente académico, si en su sentido más usual o corriente, aquel con el que se suele considerar a quien desempeña dicha función como una especie de subalterno que generalmente somete su trabajo a las pautas y exigencias del compositor.

57. De otra parte, no había sido esta la primera vez que García Malo se descolgaba con esa exacta determinación de supeditar enteramente la música en provecho del argumento, ya que más o menos por esas mismas fechas lo dejaba declarado también en el "Discurso preliminar» a su traducción de El Demofoonte, confesando sin rubor allí haber expurgado numerosas arias que en nada contribuían "al interés de la acción». Y acto seguido razonaba así sobre ese cercenamiento: «Pareciéndome que solo servirían para hacer lánguida la Escena, y que sus conceptos son verdaderamente líricos, mas no patéticos ni propios de un Drama trágico» ("Discurso preliminar». En El Demofoonte, op. cit., pp. XIII-XIV). 
miras de continuo puestas en favorecer el bien común ${ }^{58}$, a crear una ópera como Glaura y Cariolano y a intentar, de paso con ella, sentar los cimientos de un futuro teatro lírico en España que nada tuviera que envidiar al italiano.

58. Aún en los años finales de su vida tiene siempre bien presente ese principio: "Todo escrito debe tener por objeto la utilidad pública" (GARCíA MALO, Ignacio. "Advertencia» a Los derechos de la soberanía nacional. Contra el despotismo y la hipocresía. Palma de Mallorca: Imprenta Real, 1810, h. s. n.). 